\title{
THE DEMISE OF THE LARGEST AND OLDEST AFRICAN BAOBABS
}

\author{
Adrian Patrut ${ }^{1 *}$, Stephan Woodborne ${ }^{2}$, Roxana T. Patrut ${ }^{3}$, Laszlo Rakosy ${ }^{3}$, \\ Daniel A. Lowy ${ }^{4}$, Grant Hall ${ }^{5}$, Karl F. von Reden ${ }^{6}$
}

${ }^{1}$ Faculty of Chemistry and Chemical Engineering, Babes-Bolyai University, Cluj-Napoca, Romania.

${ }^{2}$ iThemba LABS, Private Bag 11, WITS 2050, South Africa.

${ }^{3}$ Faculty of Biology and Geology, Babes-Bolyai University, Cluj-Napoca, Romania.

${ }^{4}$ Department of Science and Engineering, Nova University, Alexandria Campus, Alexandria, VA, U.S.A.

${ }^{5}$ Mammal Research Institute, University of Pretoria, South Africa.

${ }^{6}$ NOSAMS Facility, Department of Geology \& Geophysics, Woods Hole Oceanographic Institution, Woods Hole, MA, U.S.A.

*e-mail: apatrut@gmail.com

\begin{abstract}
The African baobab is the biggest and longest living angiosperm tree. By using radiocarbon dating we identified the stable architectures that enable baobabs to reach large sizes and old ages. We report that 9 of the 13 oldest and 5 of the 6 largest individuals have died or at least their oldest parts/stems have collapsed and died over the past 12 years; the cause of the mortalities is still unclear.
\end{abstract}


The African baobab (Adansonia digitata L.) has a natural distribution in the savanna regions of Africa between the latitudes $16^{\circ} \mathrm{N}$ and $26^{\circ} \mathrm{S}$. It is also found outside Africa in tropical areas, where it has been introduced ${ }^{1-3}$. The biggest and oldest specimens may have wood volumes of $300-500 \mathrm{~m}^{3}$ and reach ages close to 2,000 years; by these values the African baobab is the largest and longest living angiosperm tree $e^{4,5}$.

In 2005 we started an in-depth research program to elucidate several controversial or poorly understood aspects of the architecture, growth and age of the African baobab. The research is based on our new approach, which is not limited to fallen specimens, but also allows to investigate and date live specimens. The approach consists of AMS (accelerator mass spectrometry) radiocarbon dating of small wood samples collected from inner cavities and/or from different areas of their trunk/stems ${ }^{4}$.

This research has revealed that big African baobabs are always multi-stemmed. The majority of baobabs start growing as single-stemmed trees. Over time, single-stemmed individuals become multi-stemmed, owing to the baobabs' ability to produce periodically new stems, such as other tree species produce branches. By this special ability, baobabs develop over time architectures of increasing complexity. Therefore, we focused on the investigation of superlative individuals, i.e., very large and potentially old baobabs. One should emphasize that neither the identification of such very complex architectures nor the accurate age determination of old baobabs are possible via traditional dendrochronological methods based on tree ring investigation. The radiocarbon investigation of large African baobabs has revealed that their architecture is much more complex and idiosyncratic than previously believed ${ }^{6,7}$.

Our research has identified a new type of architecture that enables African baobabs to reach old ages and large sizes. In this architecture, the multiple stems define at ground level a circle or an ellipse, with an empty space between them; we named it ring-shaped structure (RSS). There are 
two subtypes of RSSs. The only one obvious to visual observation is the open RSS in which the stems are fused or knitted at the base, are pointed sideways, have quasi-cylindrical shapes and quasi-circular transversal sections ${ }^{5,7}$. The most frequent is, however, the closed RSS in which the stems are pointed upward and are fused almost perfectly. The fused stems are disposed in a ring with an empty space inside. We termed this natural empty space between the fused stems false cavity $^{6,7}$.

According to dating results, open and closed RSSs have formed progressively and closed over time as they usually consist of 3-8 stems belonging to several generations. Certain individuals have additional stems outside the $\operatorname{ring}(\mathrm{s})$.

Many old baobabs have large hollow parts, mainly in the central area of their trunk/stems. Large normal cavities are formed by wood loss (due to fungi decay, fire, elephant damage) and the pith/centre is located inside the cavity. The age values of samples collected from normal cavities decrease continuously from the cavity walls toward the outer part of the trunk/stem ${ }^{7}$.

In most cases we found, however, that the age sequence shows a continuous increase from the cavity walls up to a certain distance into the wood, after which it decreases toward the outer part. The only reasonable explanation is that such cavities are in fact false cavities, i.e., natural empty spaces between fused stems disposed in a closed RSS. The thickness of the fused stems that define the false cavity is of only 1-2 m. The oldest part of the fused stems is located between the false cavity walls and the outer part/exterior of each stem, always closer to the cavity, in an area which would be accessible to the increment borer and allows to collect very old samples ${ }^{6,7}$ (Supplementary Figure 1a-d).

The first noticeable difference between false and normal cavities is the presence or absence of bark inside the cavity. While normal cavities become larger over time due to continuous decay, false cavities become smaller due to stem growth. Similarly to the closed RSSs, the false cavities 
inside them close progressively. Several false cavities have closed completely over time retaining only one or several small openings. The closed RSSs with their false cavities represent the most enigmatic architecture of the African baobab. We found that this structure is characteristic exclusively to baobabs, i.e., to trees that belong to the Adansonia genus $^{6-8}$.

In the time frame 2005-2017, we investigated and dated practically all known very large and potentially old African baobab specimens (over 60 trees) from northern and southern continental Africa, African islands and outside Africa ${ }^{4-8}$. The main data and dating results of the oldest 13 specimens (numbered 1 to 13) and of the largest 6 specimens, in terms of wood volume (marked 21 to 26), are shown in Table 1 (see also Supplementary Tables 1,2).

The most unexpected and intriguing fact is that since 2005, 9 of the 13 oldest African baobab specimens and 5 of the 6 largest individuals (marked in blue in Table 1) have died or at least their largest and/or oldest parts/stems have collapsed and died. All 15 superlative trees listed in Table 1 are or were located in southern Africa (5 in South Africa, 4 in Namibia, 3 in Zimbabwe and one each in Botswana, Mozambique and Zambia), which is the home of the oldest and largest African baobabs. Nine individuals exhibit or exhibited a closed RSS (Panke, Holboom, Humani Bedford, Matendere, Luna, Lebombo, Lundu, Platland, Sagole), while 4 individuals have or had an open RSS (Dorslandboom, Glencoe, Makuri Leboom, Chapman). Finally, one specimen had an incomplete RSS (Grootboom) and another a cluster structure (Makulu Makete).

All stems of 4 African baobabs have toppled and died (Panke in 2010-2011, Grootboom in 20042005, Chapman in 2016 and Makulu Makete in 2008). The largest and oldest stems of other 6 individuals have collapsed and died, but other smaller and younger stems survived, being still alive (Dorslandboom in 2006, Glencoe in 2009, Makuri Leboom since 2005, Holboom since 2012, Lundu since 2014 and Platland in 2016-2017). 
Here we present briefly 3 superlative trees, which were the oldest, the largest and the most famous African baobabs, that have collapsed and died recently.

Table 1 I Main data, radiocarbon and calibrated ages of the oldest and largest African baobabs

\begin{tabular}{|c|c|c|c|c|c|c|}
\hline Nr. & $\begin{array}{l}\text { Tree } \\
\text { (Location) }\end{array}$ & $\begin{array}{l}\text { Girth }^{*}(\mathrm{~m}) \\
\text { height }(\mathrm{m}) \\
\text { volume } \\
\left(\mathrm{m}^{3}\right)\end{array}$ & $\begin{array}{c}\text { Radiocarbon } \\
\text { age }^{\dagger} \\
\text { [error] } \\
\left({ }^{14} \mathrm{C} \text { yr BP }\right) \\
\end{array}$ & $\begin{array}{c}\text { Sample } \\
\text { age }^{\dagger} \\
\text { [error] } \\
\text { (cal yr) }\end{array}$ & $\begin{array}{l}\text { Calculated } \\
\text { age of } \\
\text { tree/stem } \\
\text { (cal yr) }\end{array}$ & Status \\
\hline $\begin{array}{l}1 / \\
24\end{array}$ & $\begin{array}{l}\text { Panke } \\
\text { (Mbuma, Zimbabwe) }\end{array}$ & $\begin{array}{c}25.50 \\
15.5 \\
(400) \\
\end{array}$ & $2429[ \pm 14]$ & $\begin{array}{l}2450 \\
{[+45,-40]} \\
\text { (in 2011) } \\
\end{array}$ & +2500 & $\begin{array}{l}\text { all stems toppled and } \\
\text { died in 2010-2011 }\end{array}$ \\
\hline 2 & $\begin{array}{l}\text { Dorslandboom } \\
\text { (Khaudum Park, Namibia) }\end{array}$ & $\begin{array}{c}(+30)^{*} \\
14.3 \\
(200)\end{array}$ & $1956[ \pm 21]$ & $\begin{array}{l}1915[+25] \\
\text { (in 2006) }\end{array}$ & 2100 & $\begin{array}{l}\text { the oldest } 2 \text { stems } \\
\text { toppled and died in } \\
2006\end{array}$ \\
\hline $\begin{array}{l}3 / \\
23\end{array}$ & $\begin{array}{l}\text { Glencoe tree } \\
\text { (Hoedspruit, South Africa) }\end{array}$ & $\begin{array}{c}(+30)^{*} \\
16.0 \\
(400)\end{array}$ & $1931[ \pm 14]$ & $\begin{array}{l}1905[ \pm 40] \\
\text { (in 2009) }\end{array}$ & +2000 & $\begin{array}{l}\text { the main old part split } \\
\text { and died in } 2009\end{array}$ \\
\hline $\begin{array}{l}4 / \\
26\end{array}$ & $\begin{array}{l}\text { Holboom } \\
\text { (Nyae Nyae Conserv., Namibia) }\end{array}$ & $\begin{array}{c}35.10 \\
30.2 \\
(340) \\
\end{array}$ & $1760[ \pm 18]$ & $\begin{array}{l}1700[ \pm 60] \\
\text { (in 2012) }\end{array}$ & 1800 & $\begin{array}{c}\text { several stems and } \\
\text { cavity walls broke off } \\
\text { since } 2012\end{array}$ \\
\hline 5 & $\begin{array}{l}\text { Humani Bedford Old baobab } \\
\text { (Savé Valley, Zimbabwe) }\end{array}$ & $\begin{array}{c}23.65 \\
18.2 \\
(240) \\
\end{array}$ & $1655[ \pm 14]$ & $\begin{array}{c}1585 \\
{[+35,-25]}\end{array}$ & 1800 & alive \\
\hline 6 & $\begin{array}{l}\text { Makuri Leboom } \\
\text { (Nyae Nyae Conserv., Namibia) }\end{array}$ & $\begin{array}{c}34.23 \\
14.5 \\
(200)\end{array}$ & $1602[ \pm 17]$ & $\begin{array}{c}1510 \\
{[+35,-40]}\end{array}$ & 1600 & $\begin{array}{c}\text { several old stems } \\
\text { toppled and/or } \\
\text { broke off }\end{array}$ \\
\hline $\begin{array}{l}7 / \\
25\end{array}$ & $\begin{array}{l}\text { Grootboom } \\
\text { (Nyae Nyae Conserv., Namibia) }\end{array}$ & $\begin{array}{c}30.60 \\
32.0 \\
(350) \\
\end{array}$ & $1575[ \pm 14]$ & $\begin{array}{l}1455[ \pm 20] \\
\text { (in 2005) }\end{array}$ & 1500 & $\begin{array}{l}\text { all stems toppled and } \\
\text { died in 2004-2005 }\end{array}$ \\
\hline 8 & $\begin{array}{l}\text { Matendere Big baobab } \\
\text { (Savé Valley, Zimbabwe) }\end{array}$ & $\begin{array}{c}26.30 \\
22.5 \\
(300) \\
\end{array}$ & $1529[ \pm 14]$ & $1430[ \pm 45]$ & 1500 & alive \\
\hline 9 & $\begin{array}{l}\text { Luna tree } \\
\text { (Venetia Limpopo NR, } \\
\text { South Africa) }\end{array}$ & $\begin{array}{c}20.02 \\
17.2 \\
(170) \\
\end{array}$ & $1507[ \pm 22]$ & $1405[ \pm 20]$ & 1500 & alive \\
\hline 10 & $\begin{array}{l}\text { Lebombo Eco trail baobab } \\
\text { (Limpopo NP, Mozambique) }\end{array}$ & $\begin{array}{c}21.44 \\
18.5 \\
(220)\end{array}$ & $1425[ \pm 24]$ & $1360[ \pm 10]$ & 1400 & alive \\
\hline 11 & $\begin{array}{l}\text { Chapman baobab (Makgadikgadi } \\
\text { Pans, Botswana) }\end{array}$ & $\begin{array}{c}25.90 \\
22.6 \\
(275) \\
\end{array}$ & $1381[ \pm 22]$ & $\begin{array}{c}1345 \\
{[+10,-15]} \\
\text { (in 2016) } \\
\end{array}$ & 1400 & $\begin{array}{l}\text { all stems toppled and } \\
\text { died in } 2016\end{array}$ \\
\hline 12 & $\begin{array}{l}\text { Makulu Makete Big baobab } \\
\text { (Makulu Makete Reserve, South } \\
\text { Africa) }\end{array}$ & $\begin{array}{c}22.25 \\
23.0 \\
(220) \\
\end{array}$ & $1277[ \pm 21]$ & $\begin{array}{l}1195[+45] \\
\text { (in 2008) }\end{array}$ & 1250 & $\begin{array}{l}\text { all stems toppled and } \\
\text { died in } 2008\end{array}$ \\
\hline 13 & $\begin{array}{l}\text { Lundu baobab } \\
\text { (South Luangwa NP, Zambia) }\end{array}$ & $\begin{array}{c}26.01 \\
24.6 \\
(300) \\
\end{array}$ & $1221[ \pm 26]$ & $\begin{array}{c}1190 \\
{[+75,-55]}\end{array}$ & 1250 & $\begin{array}{c}\text { several stems and } \\
\text { cavity walls broke off } \\
\text { since } 2014 \\
\end{array}$ \\
\hline 21 & $\begin{array}{l}\text { Platland tree/Sunland baobab } \\
\text { (Modjadjiskloof, South Africa) }\end{array}$ & $\begin{array}{c}34.11 \\
18.9 \\
501 \\
\end{array}$ & $978[ \pm 14]$ & $\begin{array}{c}930 \\
{[+50,-70]}\end{array}$ & 1100 & $\begin{array}{c}\text { the largest unit } \\
\text { toppled and died in } \\
2016-2017 \\
\end{array}$ \\
\hline 22 & $\begin{array}{l}\text { Sagole Big tree } \\
\text { (Zwigodini / Mutale, South Africa) }\end{array}$ & $\begin{array}{c}34.35 \\
20.3 \\
414\end{array}$ & $781[ \pm 29]$ & $740[ \pm 15]$ & 850 & alive \\
\hline
\end{tabular}

Specimens which toppled completely or partially are marked in blue; Estimated values are in small brackets; ${ }^{*}$ circumference at $1.30 \mathrm{~m} ;{ }^{\dagger}$ of the oldest dated sample/segment; ${ }^{\star}$ unmeasurable because of collapsed stems. 
Panke (Nr. 1 and 24 in Table 1; Supplementary Figure 2) was a sacred baobab located in a remote area from Matabeleland North, Zimbabwe ${ }^{9,10}$. It had a closed RSS, with a ring defined by 3 fused stems around a false cavity with a low entrance; it also had 3 additional stems. In 2010, the remaining branches started to break off and collapsed successively; next, the stems split and toppled one after another over a period of more than one year. We collected and dated several samples from its remains. The oldest sample had a radiocarbon age of $2419 \pm 14 \mathrm{BP}$, which corresponds to a calibrated calendar age of ca. $2450 \mathrm{yr}$. By this value, Panke becomes the oldest African baobab and angiosperm with accurate dating results.

The Platland tree, a.k.a. Sunland baobab (Nr. 21; Supplementary Figure 3), situated in Limpopo province, South Africa, was probably the most promoted and visited African baobab ${ }^{4,11}$. Platland was the biggest known African baobab and angiosperm ${ }^{4}$, with a total wood volume of $501 \mathrm{~m}^{3}$. Its huge trunk has a double closed RSS and consists of two units, composed of two rings with two interconnected false cavities. The largest unit split four times in 2016 and 2017 and all its 5 stems toppled and died.

The most famous historic baobab, i.e., the Chapman baobab (Nr. 11; Figure1), was located close to the Makgadikgadi Pans of Central Botswana ${ }^{7}$. It was named after the South African hunter James Chapman, who visited the tree in 1852. The Chapman baobab had an open RSS, with 6 partially fused stems that belonged to three generations which were 1400, 800-1000 and 500-600 yr old. On January 7, 2016, the 6 stems of Chapman toppled simultaneously and died.

The death of the majority of the oldest and largest African baobabs over the past 12 years is an event of an unprecedented portent. The death of the majority of the oldest and largest African baobabs over the past 12 years is an event of an unprecedented portent. These demises were not caused by an epidemic and there has also been a rapid increase in the apparently natural death of many other mature baobabs. We suspect that the demise of monumental baobabs may be 
associated at least in part with significant modifications of climate conditions which affect especially southern Africa ${ }^{12}$. However, further research is necessary to support or to infirm this supposition.
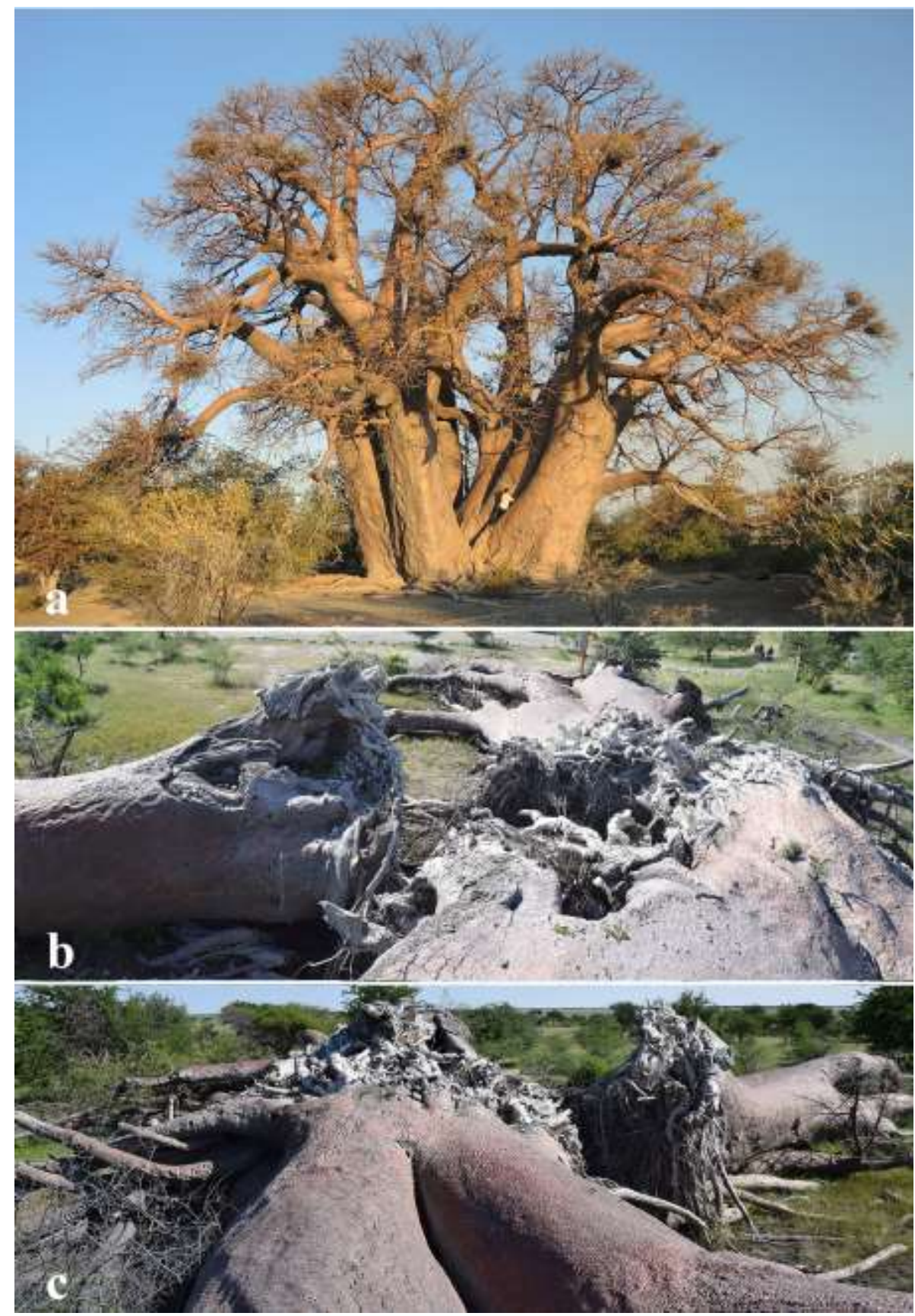

Figure 1 । Life and death of the historic Chapman baobab. a, General view of the Chapman baobab in June 2015, showing its open ring-shaped structure which consisted of 6 stems. b and c, Photographs showing the baobab just after its sudden collapse in January 2016. The tree lies on the ground almost intact, with unbroken stems and branches. 


\section{METHODS}

Metric measurements. The height of the investigated baobabs was measured when they still had standing stems, by using a Bosch Professional laser rangefinder and a Suunto clinometer. The circumference at breast height, i.e., at $1.30 \mathrm{~m}$ above ground level (cbh), was measured with graduated tapes. The overall wood volume was determined accurately for the two largest specimens (Platland, Sagole) ${ }^{4}$ by using Criterion survey lasers. For the other individuals, the overall volume was estimated from laser measurements of the stems at different heights, as well as of the large branches. For two specimens that toppled completely and died prior to our initial investigations (Panke, Grootboom), we adopted the dimensions measured previously by other researchers.

Sample collection. Several tiny wood samples were collected from the inner cavities and/or different areas of the outer part of stems at convenient heights between 1.00-2.20 m, as well as from fallen/broken stems of live baobabs. The sampling was performed by using Haglöf increment borers with lengths of $0.60-1.50 \mathrm{~m}$ (inner diametre $0.54-1.08 \cdot 10^{-2} \mathrm{~m}$ ). In some cases, we also collected samples from the remains of dead specimens. Segments with lengths of $10^{-3} \mathrm{~m}$ were extracted from determined positions of the original samples.

Radiocarbon measurements. After pretreatment, the sample segments were finally reduced to graphite $^{7,8}$. The AMS radiocarbon investigation of the graphite samples was performed at the NOSAMS Facility of the Woods Hole Oceanographic Institution, Woods Hole, MA, U.S.A., by using the Pelletron ${ }^{\circledR}$ Tandem $500 \mathrm{kV}$ AMS system. The obtained fraction modern values corrected for isotope fractionation were ultimately converted to radiocarbon ages. Radiocarbon ages of the oldest sample segments originating from each of the investigated baobabs are listed in Table 1 and in Supplementary Table 2. Radiocarbon ages and errors were rounded to the nearest year. 
Calibration. Radiocarbon ages were calibrated and converted into calendar ages with the OxCal v4.3 for Windows ${ }^{13}$, by using the SHCal13 atmospheric data $\operatorname{set}^{14}$ for the Southern Hemisphere.

Calibrated ages. The $1 \sigma$ probability distribution $(68.2 \%)$ was typically selected to derive calibrated age ranges. For 7 sample segments the $1 \sigma$ distribution is consistent with one range of calendar years, while for other 3 segments the $1 \sigma$ distribution corresponds to two ranges. For these 3 segments, the confidence interval of one range is considerably greater than that of the others; therefore, it was selected as the cal $\mathrm{AD}$ range of the sample segment (marked in italics) for the purpose of this discussion. However, for 5 sample segments, there are several $1 \sigma$ ranges with close confidence intervals. In these special cases (Glencoe, Holboom, Matendere, Lundu, Platland), we used the higher $2 \sigma$ probability distribution $(95.4 \%)$ for calibration, which corresponds to one or two ranges of calendar years for each date. We selected the range with the highest probability as the cal $\mathrm{AD}$ range of each sample segment (marked in italics) for the purpose of this discussion. The cal $\mathrm{AD}$ ranges for all 15 radiocarbon ages are displayed in Supplementary Table 2. For obtaining single age values, which correspond each to an assigned year, we derived a mean value for the 15 selected age ranges; this mean value divides the range graphically in two equal areas ${ }^{7}$. The assigned years for the 15 sample segments are presented in Supplementary Table 2 .

Sample ages. Sample ages, expressed in calendar years, represent the difference between AD 2017 (or the year when the stem died) and the mean value of the selected range. Sample ages and errors were rounded to the nearest 5 years.

Tree/stem ages. The tree/stem ages were calculated by extrapolating the oldest sample ages to the calculated position of the stem's pith. Sample ages and tree/stem ages are shown in Table 1 and Supplementary Table 2. 
Data availability. The authors declare that all data supporting the findings of this study are available within the article. The NOSAMS Accession Numbers for the disclosed radiocarbon measurements are included in Supplementary Table 2. All figures are original photographs taken by the authors, with the exception of Supplementary Figure 2 which was taken in 1997 by Jocelyn Alexander, who authorised its publication.

\section{REFERENCES}

1. Wickens, G. E. \& Lowe, P. The Baobabs: Pachycauls of Africa, Madagascar and Australia (Springer, 2008).

2. Wickens, G. E. Kew Bull. 47, 173-209 (1983).

3. Baum, D. A. Ann. Mo. Bot. Gard. 82, 440-471 (1995).

4. Patrut A. et al. Ann. Forest Sci. 68, 993-1003 (2011).

5. Patrut, A., von Reden, K. F., Mayne, D. H., Lowy, D. A. \& Patrut, R. T. Nucl. Instr. Meth. B 294, 622-626 (2013).

6. Patrut, A. et al. PLoS ONE 10, e0117193 (2015).

7. Patrut, A. et al. Radiocarbon 59, 435-448 (2017).

8. Patrut, A. et al. Tree Physiol. 27, 1569-1574 (2007).

9. Alexander, J., McGregor, J. A. \& Ranger, T. Violence \& Memory, One Hundred years in the 'Dark Forests' of Matabeleland (Currey, 2000).

10. Mullin, L. J. Historic trees of Zimbabwe (CBC, 2003).

11. Patrut, A. et al. Radiocarbon 52(2-3), 717-726 (2010).

12. Engelbrecht, F. et al. Environ. Res. Lett. 10, 085004 (2015).

13. Bronk Ramsey, C. et al. Radiocarbon 51, 337-360 (2009).

14. Hogg, A. G. et al. Radiocarbon 55, 1889-1903 (2013). 


\section{Acknowledgements}

The investigation and collection of samples from the trees was approved and authorised by The South African National Parks, The Kruger National Park, The Mapungubwe National Park, The Ministry of Environment and Tourism of Namibia and The Department of Wildlife and National Parks of Botswana, The South Luangwa National Park. We thank Heather and Doug van Heerden, Peter Philips and Jane Chidgey, Cecil and Yvonne Liversage, Leon Duplessis, Roger and Anne Whittall for granting permission for on-site investigation of baobabs located on their private lands. We also thank Diana H. Mayne, Michele Hofmeyr, Sarah Venter, Andries Alberts, Rudolf Wittmann, Davidson Dube and Oma (Leon) Tsamkgao for helping to obtain permits and for participating at several field investigations. Special thanks to Jocelyn Alexander for providing the photograph of Panke. This research was supported by the Romanian Ministry of National Education CNCS-UEFISCDI under grant PN-II-ID-PCE-2013-76 and by the Romanian Ministry of Research and Innovation CNCS-UEFISCDI under grant PN-III-P4-ID-PCE-2016-0776, Nr. 90/2017.

\section{Author contributions}

A.P. conceived the research, A.P., S.W., R.T.P., L.R. and G.H. performed field investigations and collected samples, K.F.v.R. performed AMS measurements, A.P., S.W., R.T.P. and D.A.L. interpreted results and wrote the manuscript.

\section{Competing interests}

The authors declare to have no competing interests. 


\section{Supplementary information}

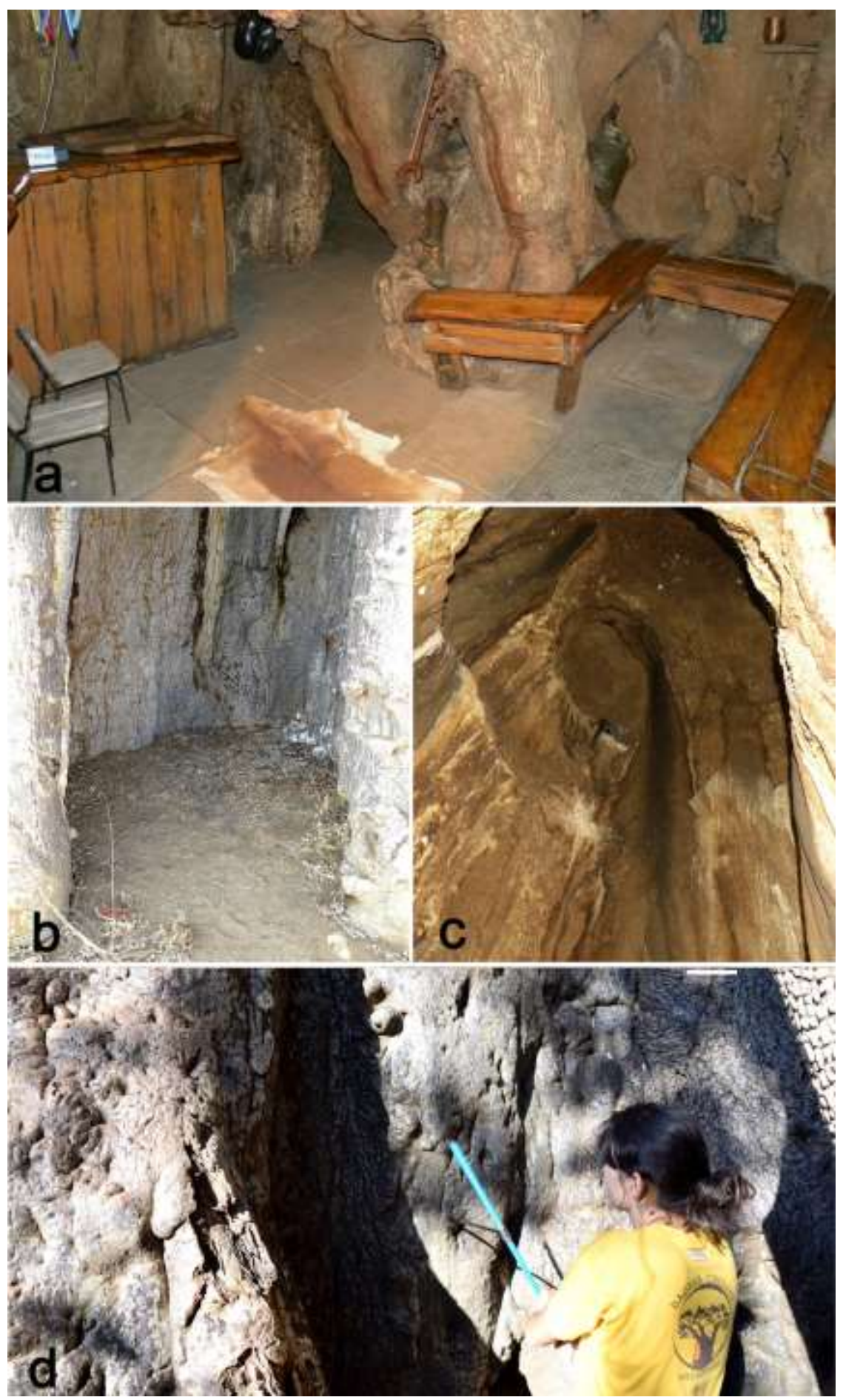

Supplementary Figure 1 I False cavities. a, The largest false cavity of Platland tree housed an original bar for more than a decade. $\mathbf{b}$, The base of the false cavity of the Lebombo baobab has a typical quasi-ellipsoidal shape. c, The Luna tree has the characteristic ceiling of false cavities. d, Collecting old samples from the false cavity of the Humani Bedford Old baobab. 


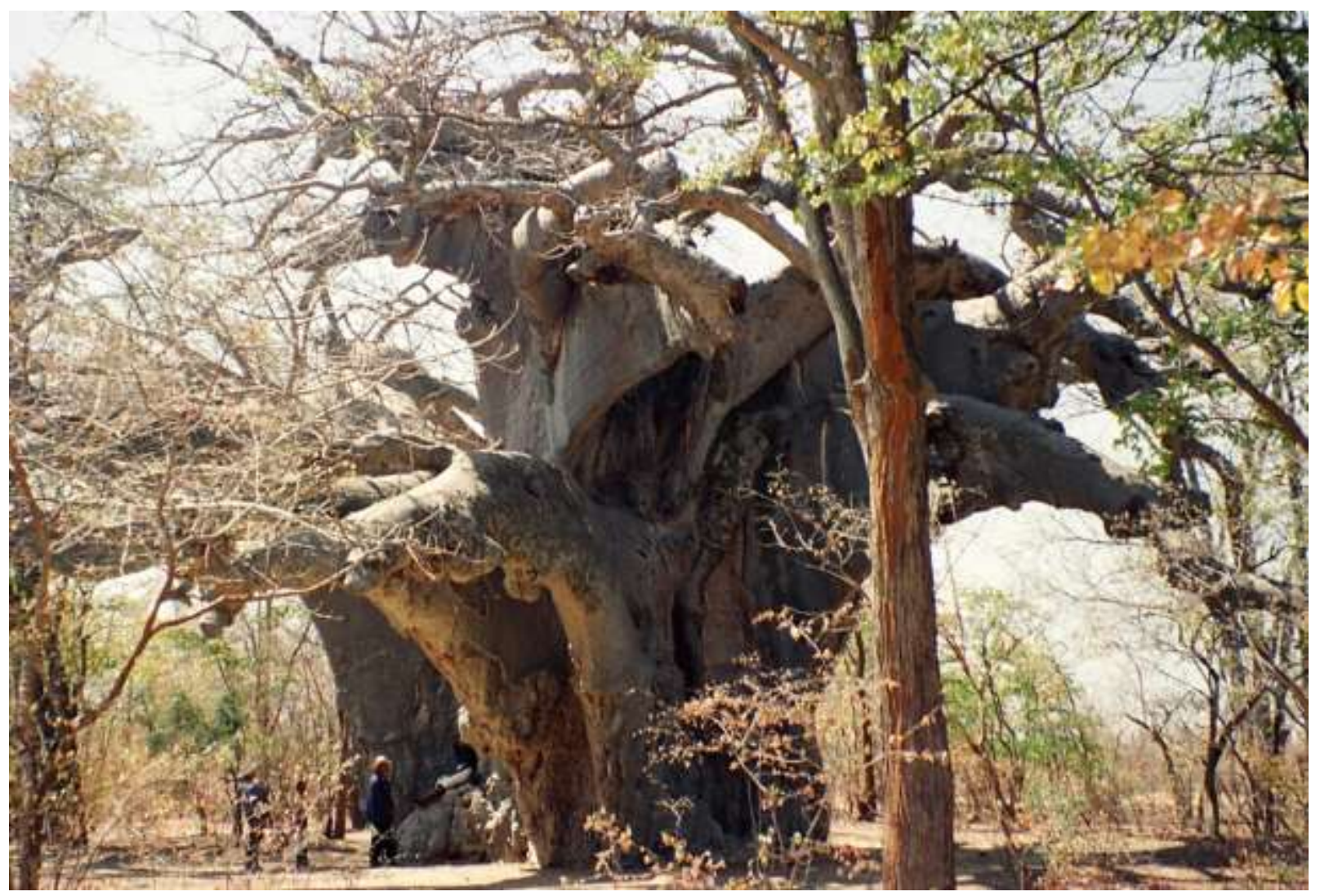

Supplementary Figure 2 | Panke, the oldest known African baobab. This is a unique image showing the old Panke in 1997 with many missing and broken branches.

This photograph was taken by Jocelyn Alexander, who authorised its publication. 

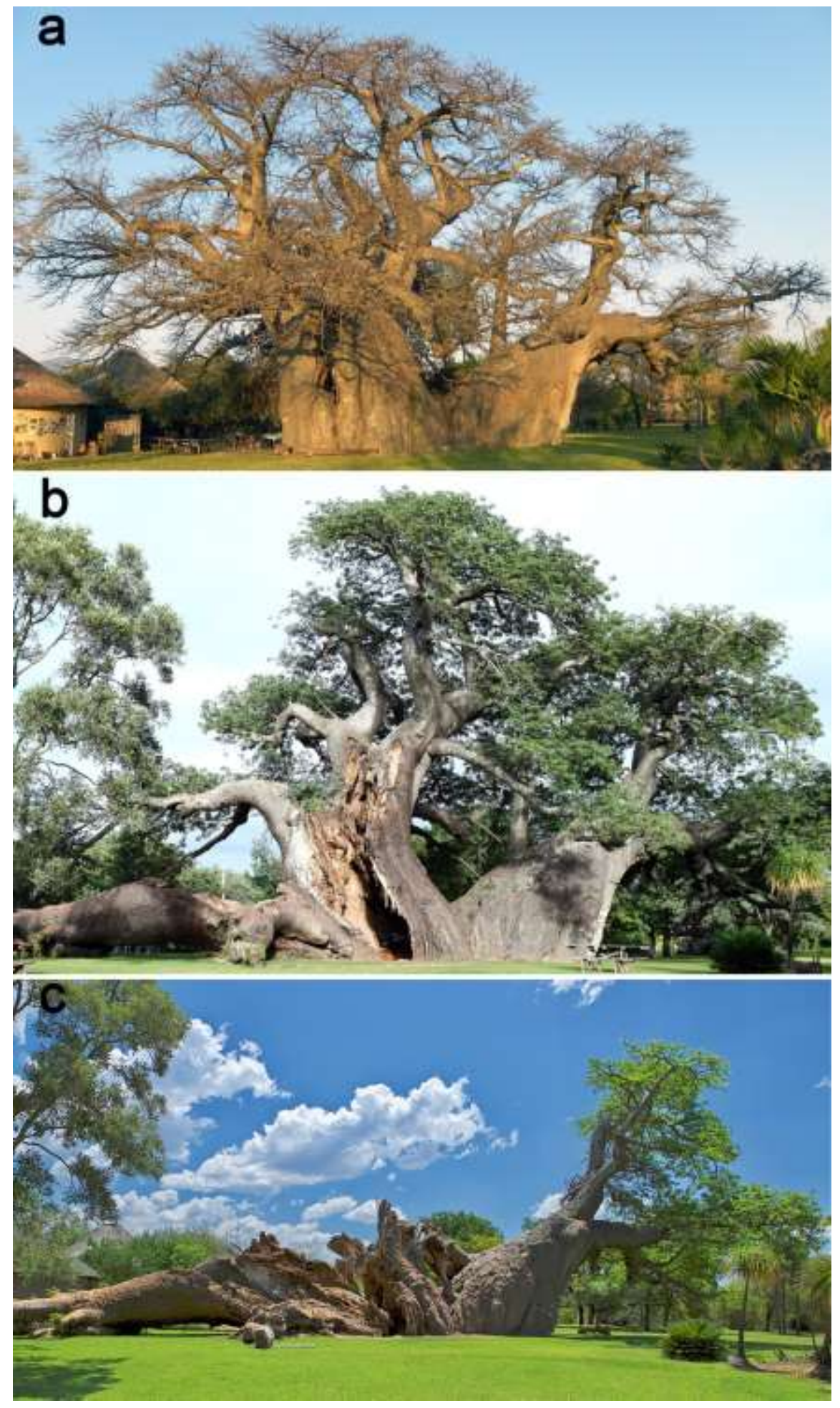

Supplementary Figure 3 । Platland tree, the largest known African baobab. a, General view of the Platland tree showing its two multi-stemmed units, when it was still the largest baobab. $\mathbf{b}$, View of the tree after the first two splits of May and August 2016. Two stems of the largest unit have toppled. c, The Platland tree after the last two splits of April and November 2017. All 5 stems of the largest unit have toppled and died. 
Supplementary Table 1 I Main data of the oldest and largest African baobabs

\begin{tabular}{|c|c|c|c|c|}
\hline $\mathrm{Nr}$. & $\begin{array}{l}\text { Tree } \\
\text { (Location) }\end{array}$ & $\begin{array}{l}\text { GPS } \\
\text { [Altitude }(\mathrm{m}) / \\
\text { rainfall }(\mathrm{mm})]\end{array}$ & $\begin{array}{l}\operatorname{Girth}^{*}(\mathrm{~m}) \\
\text { height }(\mathrm{m}) \\
\text { volume }\left(\mathrm{m}^{3}\right)\end{array}$ & Architecture and remarks \\
\hline $\begin{array}{l}1 / \\
24\end{array}$ & $\begin{array}{l}\text { Panke (Mbuma, Nkayi, } \\
\text { Matabeleland North, } \\
\text { Zimbabwe) }\end{array}$ & $\begin{array}{c}18^{\circ} 52.276^{\prime} \mathrm{S} \\
028^{\circ} 28.418^{\prime} \mathrm{E} \\
{[1077 / 642]}\end{array}$ & $\begin{array}{l}25.50 \\
15.5 \\
(400)\end{array}$ & $\begin{array}{l}\text { closed RSS, } 3 \text { stems that close a false cavity }+ \\
3 \text { additional stems; all stems toppled and died } \\
\text { in } 2010-2011\end{array}$ \\
\hline 2 & $\begin{array}{l}\text { Dorslandboom } \\
\text { (S of Khaudum Park, } \\
\text { Otjozondjupa, Namibia) }\end{array}$ & $\begin{array}{c}19^{\circ} 18.061^{\prime} \mathrm{S} \\
020^{\circ} 39.686^{\prime} \mathrm{E} \\
{[1128 / 451]}\end{array}$ & $\begin{array}{c}(+30)^{\dagger} \\
14.3 \\
(200)\end{array}$ & $\begin{array}{l}\text { open RSS with } 8 \text { toppled or standing old stems } \\
+2 \text { additional young stems; the } 2 \text { oldest fused } \\
\text { stems died in } 2006\end{array}$ \\
\hline $\begin{array}{l}3 / \\
23\end{array}$ & $\begin{array}{l}\text { Glencoe tree } \\
\text { (Glencoe farm, } \\
\text { Hoedspruit, Limpopo, } \\
\text { South Africa) }\end{array}$ & $\begin{array}{c}24^{\circ} 22.430^{\prime} \mathrm{S} \\
030^{\circ} 51.461^{\prime} \mathrm{E} \\
{[472 / 439]}\end{array}$ & $\begin{array}{c}(+30)^{\dagger} \\
16.0 \\
(+400)\end{array}$ & $\begin{array}{l}\text { open RSS; } 7 \text { old toppled stems + } 9 \text { young } \\
\text { stems; in } 2009 \text {, it split twice, exposing } 2 \\
\text { cavities; the main old part died in } 2009\end{array}$ \\
\hline $\begin{array}{l}4 / \\
26\end{array}$ & $\begin{array}{l}\text { Holboom } \\
\text { (Nyae Nyae Conserv., } \\
\text { Otjozondjupa, Namibia) }\end{array}$ & $\begin{array}{c}19^{\circ} 40.674^{\prime} \mathrm{S} \\
020^{\circ} 37.082^{\prime} \mathrm{E} \\
{[1148 / 451]}\end{array}$ & $\begin{array}{c}35.10 \\
30.2 \\
(340) \\
\end{array}$ & $\begin{array}{l}\text { closed double RSSs, } 5 \text { fused stems that close } \\
2 \text { false cavities }+2 \text { additional stems; } 3 \text { stems } \\
\text { and cavity walls broke off since } 2012\end{array}$ \\
\hline 5 & $\begin{array}{l}\text { Humani Bedford } \\
\text { Old baobab (Humani } \\
\text { ranch, Savé Valley, } \\
\text { Chiredzi, Zimbabwe) } \\
\end{array}$ & $\begin{array}{c}20^{\circ} 24.474^{\prime} \mathrm{S} \\
032^{\circ} 14.135^{\prime} \mathrm{E} \\
{[432 / 457]}\end{array}$ & $\begin{array}{l}23.65 \\
18.2 \\
(240)\end{array}$ & $\begin{array}{l}\text { closed RSS with } 3 \text { fused stems that close a } \\
\text { false cavity; one stem of the ring is missing }\end{array}$ \\
\hline 6 & $\begin{array}{l}\text { Makuri Leboom } \\
\text { (Nyae Nyae Conserv., } \\
\text { Otjozondjupa, Namibia) }\end{array}$ & $\begin{array}{c}19^{\circ} 39.404^{\prime} \mathrm{S} \\
020^{\circ} 47.143^{\prime} \mathrm{E} \\
{[1169 / 451]}\end{array}$ & $\begin{array}{l}34.23 \\
14.5 \\
(200)\end{array}$ & $\begin{array}{l}\text { open RSS, } 12 \text { stems of different ages, out of } \\
\text { which } 2 \text { toppled, } 4 \text { are broken and one is } \\
\text { missing }\end{array}$ \\
\hline $\begin{array}{l}7 / \\
25\end{array}$ & $\begin{array}{l}\text { Grootboom } \\
\text { (Nyae Nyae Conserv., } \\
\text { Otjozondjupa, Namibia) }\end{array}$ & $\begin{array}{c}19^{\circ} 38.958^{\prime} \mathrm{S} \\
020^{\circ} 39.395^{\prime} \mathrm{E} \\
{[1119 / 451]}\end{array}$ & $\begin{array}{c}30.60 \\
32.0 \\
(350) \\
\end{array}$ & $\begin{array}{l}\text { incomplete RSS; } 6+1 \text { fused stems of different } \\
\text { ages, which collapsed successively and died in } \\
2004-2005\end{array}$ \\
\hline 8 & $\begin{array}{l}\text { Matendere Big baobab } \\
\text { (Matendere ranch, } \\
\text { Savé Valley, Chiredzi, } \\
\text { Zimbabwe) }\end{array}$ & $\begin{array}{c}20^{\circ} 00.325^{\prime} \mathrm{S} \\
032^{\circ} 03.808^{\prime} \mathrm{E} \\
{[702 / 457]}\end{array}$ & $\begin{array}{l}26.30 \\
22.5 \\
(300)\end{array}$ & $\begin{array}{l}\text { closed RSS; } 5 \text { fused stems that close a false } \\
\text { cavity }+2 \text { additional stems }\end{array}$ \\
\hline 9 & $\begin{array}{l}\text { Luna tree } \\
\text { (Venetia Limpopo NR, } \\
\text { Limpopo, South Africa) }\end{array}$ & $\begin{array}{c}22^{\circ} 22.830^{\prime} \mathrm{S} \\
029^{\circ} 22.065^{\prime} \mathrm{E} \\
{[682 / 366]}\end{array}$ & $\begin{array}{c}20.02 \\
17.2 \\
(170)\end{array}$ & $\begin{array}{l}\text { closed double RSS; } 3+4 \text { fused stems that close } \\
2 \text { connected false cavities; } 2 \text { deep incisions }\end{array}$ \\
\hline 10 & $\begin{array}{l}\text { Lebombo Eco trail } \\
\text { baobab (Limpopo NP, } \\
\text { Mozambique) }\end{array}$ & $\begin{array}{c}23^{\circ} 15.765^{\prime} \mathrm{S} \\
031^{\circ} 33.309^{\prime} \mathrm{E} \\
{[290 / 438]}\end{array}$ & $\begin{array}{c}21.44 \\
18.5 \\
(220) \\
\end{array}$ & $\begin{array}{l}\text { closed RSS; } 5 \text { fused stems that close almost } \\
\text { completely a central false cavity; } 1 \text { old stem is } \\
\text { missing }\end{array}$ \\
\hline 11 & $\begin{array}{l}\text { Chapman baobab } \\
\text { (Ntwetwe Pan, } \\
\text { Makgadikgadi Pans, } \\
\text { Central, Botswana) } \\
\end{array}$ & $\begin{array}{c}20^{\circ} 29.404^{\prime} \mathrm{S} \\
025^{\circ} 14.977^{\prime} \mathrm{E} \\
{[905 / 450]}\end{array}$ & $\begin{array}{l}25.90 \\
22.6 \\
(275)\end{array}$ & $\begin{array}{l}\text { historic tree; open RSS with } 6 \text { main } \\
\text { stems of different ages, which toppled } \\
\text { simultaneously and died in } 2016\end{array}$ \\
\hline 12 & $\begin{array}{l}\text { Makulu Makete Big } \\
\text { baobab (Makulu Makete } \\
\text { Reserve, Alldays, } \\
\text { Limpopo, South Africa) } \\
\end{array}$ & $\begin{array}{c}22^{\circ} 34.584^{\prime} \mathrm{S} \\
028^{\circ} 52.261^{\prime} \mathrm{E} \\
{[719 / 388]}\end{array}$ & $\begin{array}{l}22.25 \\
23.0 \\
(220)\end{array}$ & $\begin{array}{l}\text { cluster structure; } 4 \text { fused stems; in } 2008 \text {, the } \\
\text { tree split exposing a large cavity; eventually, } \\
\text { all split sections collapsed and died }\end{array}$ \\
\hline 13 & $\begin{array}{l}\text { Lundu baobab (Lundu } \\
\text { plain, South Luangwa NP, } \\
\text { Zambia) }\end{array}$ & $\begin{array}{c}12^{\circ} 31.258^{\prime} \mathrm{S} \\
031^{\circ} 49.754^{\prime} \mathrm{E} \\
{[612 / 817]}\end{array}$ & $\begin{array}{c}26.01 \\
24.6 \\
(300)\end{array}$ & $\begin{array}{l}\text { closed RSS; } 4 \text { fused stems that close a false } \\
\text { cavity }+3 \text { additional stems; } 3 \text { stems toppled } \\
\text { and died and cavity walls broke off since } 2014\end{array}$ \\
\hline 21 & $\begin{array}{l}\text { Platland tree/ Sunland } \\
\text { baobab (Platland farm, } \\
\text { Modjadjiskloof, Limpopo, } \\
\text { South Africa) }\end{array}$ & $\begin{array}{c}23^{\circ} 37.255^{\prime} \mathrm{S} \\
030^{\circ} 11.884^{\prime} \mathrm{E} \\
{[719 / 543]}\end{array}$ & $\begin{array}{c}34.11 \\
18.9 \\
501\end{array}$ & $\begin{array}{l}\text { closed double RSS; } 2 \text { large units defined by } \\
5+3 \text { fused stems, with } 2 \text { connected false } \\
\text { cavities; the largest unit toppled in } 2016-2017 \\
\text { and died }\end{array}$ \\
\hline 22 & $\begin{array}{l}\text { Sagole Big tree } \\
\text { (Zwigodini / Mutale, } \\
\text { Limpopo, South Africa) }\end{array}$ & $\begin{array}{c}22^{\circ} 30.002^{\prime} \mathrm{S} \\
030^{\circ} 37.995^{\prime} \mathrm{E} \\
{[359 / 354]}\end{array}$ & $\begin{array}{c}34.35 \\
19.8 \\
414 \\
\end{array}$ & $\begin{array}{l}\text { closed RSS; large unit composed of } 4+2 \text { fused } \\
\text { stems that close a false cavity }+2 \text { leaning } \\
\text { stems }\end{array}$ \\
\hline
\end{tabular}


Specimens which toppled are marked in blue; estimated values are included in round brackets; *circumference at $1.30 \mathrm{~m}$; †unmeasurable because of collapsed stems;

Supplementary Table 2 | Radiocarbon and calibrated ages of the oldest and largest baobabs

\begin{tabular}{|c|c|c|c|c|c|c|c|}
\hline Nr. & $\begin{array}{l}\text { Tree } \\
\text { (Location) }\end{array}$ & $\begin{array}{l}\text { Radiocarbon } \\
\text { age* }[\text { error] } \\
\left({ }^{14} \mathrm{C} \text { yr BP }\right)\end{array}$ & $\begin{array}{c}\text { Cal AD range }(\mathrm{s})^{* \dagger} \\
1-\sigma \text { or } 2-\sigma \\
\text { [probability] }\end{array}$ & $\begin{array}{l}\text { Assigned } \\
\text { year } \\
\text { [error] }\end{array}$ & $\begin{array}{c}\text { Sample } \\
\text { age* [error] } \\
\text { (cal yr) }\end{array}$ & $\begin{array}{l}\text { Calculated } \\
\text { age of } \\
\text { tree/stem } \\
\text { (cal yr) }\end{array}$ & $\begin{array}{c}\text { NOSAMS } \\
\text { Accession \#* }\end{array}$ \\
\hline $\begin{array}{l}1 / \\
24\end{array}$ & Panke & $2429[ \pm 14]$ & $\begin{array}{c}486 B C-402 B C \\
{[68.2 \%]}\end{array}$ & $\begin{array}{c}440 \mathrm{BC} \\
{[+46,-38]}\end{array}$ & $\begin{array}{l}2450 \\
{[+45,-40]} \\
(\text { in 2011) } \\
\end{array}$ & +2500 & OS-127079 \\
\hline 2 & Dorslandboom & $1956[ \pm 21]$ & $66-116$ [68.2\%] & $\begin{array}{c}\text { AD 93 } \\
{[+23,-27]}\end{array}$ & $\begin{array}{l}1915[ \pm 25] \\
\text { (in } 2006)\end{array}$ & 2100 & OS-87470 \\
\hline $\begin{array}{l}3 / \\
23\end{array}$ & Glencoe tree & $1931[ \pm 14]$ & $\begin{array}{c}64-140[81.1 \%] \\
180-202[14.3 \%]\end{array}$ & $\begin{array}{c}\text { AD } 103 \\
{[ \pm 38]}\end{array}$ & $\begin{array}{c}1905[ \pm 40] \\
\text { (in 2009) }\end{array}$ & +2000 & OS-116951 \\
\hline $\begin{array}{l}4 / \\
26\end{array}$ & Holboom & $1760[ \pm 18]$ & $248-371[95.4 \%]$ & $\begin{array}{c}\text { AD 310 } \\
{[+61,-62]}\end{array}$ & $\begin{array}{c}1700[ \pm 60] \\
\text { (in 2012) }\end{array}$ & 1800 & OS-85760 \\
\hline 5 & $\begin{array}{l}\text { Humani Bedford } \\
\text { Old baobab }\end{array}$ & $1655[ \pm 14]$ & $410-469$ [68.2\%] & $\begin{array}{c}\mathrm{AD} 433 \\
{[+36,-23]}\end{array}$ & $\begin{array}{c}1585 \\
{[+35,-25]}\end{array}$ & 1800 & OS-126140 \\
\hline 6 & Makuri Leboom & $1602[ \pm 17]$ & $\begin{array}{c}444-448[2.3 \%] \\
466-539[65.9 \%]\end{array}$ & $\begin{array}{c}\text { AD 505 } \\
{[+35,-39]}\end{array}$ & $\begin{array}{c}1510 \\
{[+35,-40]}\end{array}$ & 1800 & OS-126141 \\
\hline $\begin{array}{l}7 / \\
25\end{array}$ & Grootboom & $1575[ \pm 14]$ & $530-574[68.2 \%]$ & $\begin{array}{c}\text { AD 552 } \\
{[ \pm 22]}\end{array}$ & $\begin{array}{c}1455[ \pm 20] \\
\text { (in 2005) }\end{array}$ & 1600 & OS-127080 \\
\hline 8 & $\begin{array}{l}\text { Matendere } \\
\text { Big baobab }\end{array}$ & $1529[ \pm 14]$ & $545-633[95.4 \%]$ & $\begin{array}{c}\text { AD } 589 \\
{[ \pm 44]}\end{array}$ & $1430[ \pm 45]$ & 1600 & OS-118572 \\
\hline 9 & Luna tree & $1507[ \pm 22]$ & $590-633[68.2 \%]$ & $\begin{array}{c}\mathrm{AD} 612 \\
{[+21,-22]}\end{array}$ & $1405[ \pm 20]$ & 1500 & OS-87669 \\
\hline 10 & $\begin{array}{l}\text { Lebombo } \\
\text { Eco trail baobab }\end{array}$ & $1425[ \pm 24]$ & $645-667$ [68.2\%] & $\begin{array}{c}\mathrm{AD} 657 \\
{[+10,-12]}\end{array}$ & $1360[ \pm 10]$ & 1400 & OS-92686 \\
\hline 11 & $\begin{array}{l}\text { Chapman } \\
\text { baobab }\end{array}$ & $1381[ \pm 22]$ & $\begin{array}{c}655-681[63.0 \%] \\
749-753[5.2 \%]\end{array}$ & $\begin{array}{c}\mathrm{AD} 669 \\
{[+12,-15]}\end{array}$ & $\begin{array}{c}1345 \\
{[+10,-15]} \\
(\text { in 2016) } \\
\end{array}$ & 1400 & OS-95069 \\
\hline 12 & $\begin{array}{l}\text { Makulu Makete } \\
\text { Big baobab }\end{array}$ & $1277[ \pm 21]$ & $768-859$ [68.2\%] & $\begin{array}{c}\text { AD 815 } \\
{[+44,-47]}\end{array}$ & $\begin{array}{c}1195[+45] \\
\text { (in } 2008)\end{array}$ & 1250 & OS-95068 \\
\hline 13 & Lundu baobab & $1221[ \pm 26]$ & $\begin{array}{l}771-901[79.5 \%] \\
926-965[15.9 \%]\end{array}$ & $\begin{array}{c}\text { AD } 827 \\
{[+74,-56]}\end{array}$ & $\begin{array}{c}1190 \\
{[+75,-55]} \\
\end{array}$ & 1250 & OS-126073 \\
\hline 21 & $\begin{array}{l}\text { Platland tree/ } \\
\text { Sunland baobab }\end{array}$ & $978[ \pm 14]$ & $1039-1155[95.4 \%]$ & $\begin{array}{l}\text { AD 1087 } \\
{[+68,-48]}\end{array}$ & $\begin{array}{c}930 \\
{[+50,-70]} \\
\end{array}$ & 1100 & OS-119976 \\
\hline 22 & Sagole Big tree & $781[ \pm 29]$ & $\begin{array}{l}1264-1291[12.2 \%] \\
1265-1291[56.0 \%]\end{array}$ & $\begin{array}{c}\text { AD } 1278 \\
{[ \pm 13]}\end{array}$ & $740[ \pm 15]$ & 850 & OS-78676 \\
\hline
\end{tabular}

Specimens which toppled completely or partially are marked in blue; * of the oldest dated sample/segment; ${ }^{\dagger}$ the selected age range is in italics 